\title{
Native title holding communities as treaty parties
}

\author{
Greg McIntyre
}

\section{Introduction}

This paper starts from the proposition that a treaty is no more or less than an agreement which may be reached between two or more parties. The particular type of treaty which is under discussion in this paper is a treaty which may contribute to the mutual respect with which Indigenous and non-Indigenous peoples may treat each other within the Australian nation. Such treaties may take many forms, be engaged in between a variety of parties, cover a range of geographical areas and touch upon subject matter of infinite variety. The most important of such treaties are likely to be with governments and government agencies, because governments represent significant portions of the citizens of the nation.

There are many levels at which governments, corporations and non-Indigenous citizens could, and do, engage with Indigenous people, and Indigenous peoples can define themselves in various ways. Governments, corporations and citizens can treat with individuals, with local groups, extended families or clans, with regional aggregates of local groups, with dialect or language groups (sometimes called 'tribes'), with communities or peoples, with groups located within regional areas of States or Territories or with those found in a particular State or Territory, or with all those within the Australian nation.

This paper discusses the form of group which it may be most appropriate for non-Indigenous parties to seek to engage in treaties with, relying upon recent experience as to how Indigenous groups can be defined, in the context of determining native title holding groups. Consideration is given to Common Law, International law and anthropological definitions of indigenous groups.

\section{What is a communal Native title?}

In order to approach an understanding of how native title may contribute to identifying the parties to a treaty, one needs to start with an understanding of what a communal Native title is.

A communal Native title is the right to the land itself: Lee J in Ward on behalf of the Miriuwung and Gajerrong Peoples v State of Western Australia (1998) 159 ALR 483. It is not limited to the activities engaged in by the holders of such title: Delgamunkw $v$ The Queen in Right of British Columbia (Supreme Court of Canada, 11 December 1997) (1998) 1 CNLR 14. 
Communal Native title is established by occupancy of the land at the time the Crown asserted sovereignty over the land. Where an Indigenous community is in occupation of an area, its title arises from that occupation, to define the community's title as against the Crown or third parties: Kent McNeil, The Relevance of Traditional Laws and Customs to the Existence and Content of Native Title at Common Law, www.usask.ca/native law, 1996: 10; Noel Pearson, Concept of Native Title at Common Law, paper presented at Conference on Land Rights - Past, Present and Future, Canberra, 16-17 August 1996: 118; Gary Meyers, 'The Content of Native Title: Questions for the Miriuwung Gajerrong Appeal', at 6. Native title does not require proof of distinctive aboriginal practices, customs and traditions: Mabo v Queensland (No 2) (1992) 175 CLR 1 per Brennan J at 51-2, Deane and Gaudron JJ at 86, Toohey J at 184-92, 194-5, 207-14; McNeil at pp 6-17.

Occupation is established by regular use of definite tracts of the land and exploitation of its resources: Delgamunkw v The Queen in Right of British Columbia (Supreme Court of Canada, 11 December 1997) (1998) 1 CNLR 14; Toohey J in Mabo v Queensland (No 2) (1992) 175 CLR 1 at 187.

Pre-sovereignty occupation is proved by present occupation where there is no evidence to rebut the presumption that such occupation has continued since sovereignty was asserted: Delgamunkw (supra).

Provided a substantial connection between the people and the land is maintained, a change in the nature of the occupation will not preclude a finding of native title: Delgamunkw, per Lamer CJ at p 154; Mabo (No 2), per Brennan J at p 61, Deane and Gaudron JJ at 110 and Toohey $\mathrm{J}$ at p 192; Beaumont and von Doussa JJ in Western Australia $v$ Ward (2000) 170 ALR 159 at 212 and 213 (Ward FFC) ${ }^{1}$ (majority judges FFC); McNeil 1996: 29-30.

A communal Native title, by definition, includes the right of the community to exclusively use and occupy the land: Delgamuukw. Joint title can arise, however, within Aboriginal society from shared exclusivity: Delgamunkw per Lamer CJ at para 158, 196; United States v Santa Fe Railroad Co (1941) 314 US, 339. Exclusivity, in that context, means that an Aboriginal group must show that a territory is its ancestral territory and not the territory of an unconnected Aboriginal society. Two or more groups may have occupied the same territory and therefore a finding of joint occupancy is not precluded: Delgamunkw (supra).

\section{Communal Native Title rights and interests}

The Native Title Act 1993 (Cth) (NTA) s.223 (1) defines both 'native title' and 'native title rights and interests' to mean communal, group or individual rights and interests of Aboriginal peoples under traditional laws and customs which connect them to land or waters.

NTA s.225 (e) provides that a determination of native title includes a determination of 'whether the native title rights and interests confer possession, occupation use and enjoyment of ... land and waters on the native title holders to the exclusion of all others'. It reflects the order of the Court in Mabo v Queensland (No 2) (supra) that 'the Meriam people are entitled as against the whole world to possession, occupation, use and enjoyment of the land of Mer' (per Brennan J at p 76).

\footnotetext{
${ }^{1}$ Full Federal Court.
} 


\section{Communal Native Title Holding Group}

The Courts (e.g., Lee J in Ward, FC ${ }^{2}$ 1998)) have sought to come to grips with the definition of a native title holding group by posing questions to be determined of the following kind:

(a) whether there is an identifiable group which holds the native title;

(b) what kind of group the land owning group is (local descent group, clan, language group, tribe or some other entity);

(c) what social, cultural and political elements constitute that group;

(d) whether the group comprises one or more traditional societies; and

(e) whether the present claimant group (or groups) held native title to the land claimed.

The conclusion of Lee J in Ward (FC 1998), at p 541-2, was that:

there is an organised community of Aboriginal people described as Miriuwung and Gajerrong, which possesses the languages and the Ngarranggarni [Dreamings] that are part of, or run through, the claim area, being a community which observes traditional laws and customs ...

Being satisfied that there is a Miriuwung and Gajerrong community that has an ancestral connection with the Aboriginal community or communities, which occupied the claim area at the time of the assertion of sovereignty in the State or the Territory, it follows that the communal title is the title of the Miriuwung and Gajerrong people ... The inter-relation, and allocation of rights between the community and its subgroups is governed by the traditional laws and customs of the community.

The conclusions of Lee J can be related to dicta of the members of the High Court in Mabo v Queensland (No 2) (supra) where they use terms such as 'clan', 'community', 'inhabitants', 'people' and 'society', apparently interchangeably, to describe a native title holding group. Justice Brennan, for instance, said (in Mabo supra): ${ }^{3}$

(a) 'since European settlement of Australia, many clans or groups of indigenous people have been physically separated from their traditional land and have lost their connexion with it. But that is not the universal position. It is clearly not the position of the Meriam people. Where a clan or group has continued to acknowledge the laws and (so far as practicable) to observe the customs based on the traditions of that clan or group, whereby the traditional connexion with that land has been substantially maintained, the traditional community title of that clan or group can be said to remain in existence' (pp 59-60).

(b) 'Australian law can protect the interests of members of an indigenous clan or group whether communally or individually, only in conformity with the traditional laws and customs of the people to whom the clan or group belongs' ( $\mathrm{p} 60$ ).

${ }^{2}$ Federal Court. $\quad{ }^{3}$ emphasis added. 
(c) 'native title ... may be protected ... whether possessed by a community, a group or an individual' (p 61).

(d) 'the groupings of persons to possess rights and interests in land are to be determined by the laws and customs of the indigenous inhabitants' (p 61).

(e) 'Of course in time the laws and customs of any people will change and rights and interest of the members of the people among themselves will change too. But so long as the people remain as an identifiable community, the members of whom are identified by one another as members of that community living under its laws and customs, the communal native title survives to be enjoyed by the members according to the rights and interests to which they are respectively entitled under the traditionally based laws and customs as currently acknowledged and observed' (p 61).

(f) 'where an indigenous people (including a clan or group) as a community, are in possession or are entitled to possession of land under a proprietary native title, their possession may be protected or their entitlement to possession may be enforced by a representative action brought on behalf of the people or by a sub-group or individual who sues to protect or enforce rights or interests which are dependent on the communal native title... A communal native title enures for the benefit of the community as a whole and for the sub-groups and individuals within it who have particular rights and interests in the community's land' (pp 61-2).

(g) 'The recognition of the rights and interests of a sub-group or individual dependent on a community title is not precluded by an absence of a communal law to determine a point in contest between rival claimants. By custom, such a point may have to be settled by community consensus or in some other manner prescribed by custom. A court may have to act on evidence which lacks specificity in determining a question of that kind' (p 62).

Justice Brennan drew from the factual findings of Moynihan J (made on remitter from the High Court) in Mabo $v$ Queensland (No 2), the following conclusions: ${ }^{4}$

(a) 'The people who were in occupation of these Islands [the Murray Islands] before European contact and who have continued to occupy those Islands to the present are known as the Meriam people' ( $p$ 16). ${ }^{5}$

(b) 'The Meriam people of today retain a strong sense of affiliation with their forebears and with the society and culture of earlier times' (p 17).

\footnotetext{
${ }^{4}$ emphasis added. $\quad{ }^{5}$ The Plaintiffs in their Statement of Claim para 1 referred to 'the Meriam people' as 'people called the Miriam people, who speak a distinct language of their own (the Miriam language), who are known as Murray Islanders and who are included in that group of people generally known as Torres Strait Islanders'. There was no contest raised in the proceedings as to that claim. The evidentiary proceedings focused on the claims of individual plaintiffs to particular blocks of land.
} 
(c) 'The Meriam people ... are a Melanesian people (perhaps an integration of differing groups) who probably came to the Murray Islands from Papua New Guinea' (p 17). ${ }^{6}$

(d) 'Some of the features of life in the Murray Islands at the time of first European contact, at the end of the eighteenth century, are described by Moynihan J in his findings in the present case:

Communal life based on group membership seems to have been the predominant feature of life. Many of the activities of daily life were social activities which took place in the context of group activities of a ceremonial or ritualistic nature. Behaviour was regulated in the interest of the community by social pressures ... The people lived in groups of huts ... organized in named villages ... Garden land is identified by reference to a named locality coupled with the name of the relevant individuals ...

Gardening was important not only from the point of view of subsistence but to provide produce for consumption or exchange during the various rituals associated with different aspects of community life ... [or] social purposes ... and by observations and imitations reinforced by the rituals and other aspects of the social fabric gardening practices were passed on ...

... before European contact social cohesion was sought by the combined operation of a number of factors. Children were inculcated from a very early age with knowledge of their relationships in terms of social groupings and what was expected of them by a constant pattern of example, imitation and repetition with reinforcing behaviour. It was part of their environment - the way in which they lived ... Initiation and other group activities reinforced these patterns.

A sense of shame was the outcome of a failure to observe. It could be reinforced by group pressures leading to retribution. Ultimately force might be resorted to by those who had access to the means of exerting it.

Sorcery, magic and taboo were obviously important cohesive factors and a source of sanction' (p 18).

'The findings show that Meriam society was regulated more by custom than by laws' (at $\mathrm{p} 8$ ).

(e) 'Moynihan J found that there was apparently no concept of public or general community ownership among the people of Murray Island, all the land of Murray Island being regarded as belonging to individuals or groups' (at p 22).

(f) '[T]he Meriam people have maintained their own identity and their own customs'(at p 61).

\footnotetext{
${ }^{6}$ See Determination of Moynihan J delivered 16 November 1990, p 91. Justice Moynihan also found, at p 90, that there was ‘a close relationship with the other inhabitants of the Eastern Island group with whom the Murray Islanders shared a common language and, in general terms, common Papua New Guinea origins ... It seems likely that there was intermarriage between Murray Islanders and the inhabitants of at least the other of the Eastern Islands.'
} 
(g) 'Whatever be the precision of Meriam laws and customs with respect to land there is abundant evidence that land was traditionally occupied by individuals or family groups and that contemporary rights and interests are capable of being established with sufficient precision to attract declaratory or other relief' (p 62).

(h) 'Although the findings by Moynihan J do not permit a confident conclusion that, in 1879 [the date of annexation of the Islands] there were parcels of land in the Murray Islands owned allodially by individuals or groups, the absence of such a finding is not critical to the final resolution of this case' ( $\mathrm{p}$ 63).

(i) 'The plaintiffs ... claim rights and interests dependent on the native title of the Meriam people ... In the absence of any party seeking to challenge their respective claims under the laws and customs of the Meriam people, the action is not constituted in a way that permits the granting of declaratory relief with respect to claims based on those laws and customs ... Declaratory relief must therefore be restricted to the native communal title of the Meriam people' ( $\mathrm{p} 75$ ).

(j) 'the Meriam people are entitled as against the whole world to possession, occupation, use and enjoyment of the island of Mer' (p 76).

Two other judges in Mabo (No 2), Deane and Gaudron JJ, concluded from the findings of Moynihan J that:

(a) 'the Meriam people lived in an organised community which recognized individual and family rights of possession, occupation and exploitation of identified areas of land ... [U]nder the traditional law or custom of the Murray Islanders, there was a consistent focus upon the entitlement of the individual or the family as distinct from the community as a whole or some larger section of it ... [which] extended to all the land of the Islands' ( $p$ 115).

(b) 'it is impossible to identify any precise system of title, any precise rules of inheritance or any precise methods of alienation. Nonetheless, there was undoubtedly a local native system under which the established familial or individual rights of occupation and use were of a kind which far exceeded the minimum requirements necessary to found a presumptive common law native title' (pp 115-16).

(c) 'the Crown ownership of lands in the Murray Islands after their annexation to Queensland was qualified and reduced by a communal native title of the Murray Islanders to the land of the Islands ... the entitlement of particular families or individuals with respect to particular land under that common law communal title falls to be determined by reference to traditional laws and customs' ( $\mathrm{p}$ 119). 
Justice Toohey, in Mabo (No 2), said:7

(a) 'a distinction should be noted between the existence of native title and the nature of the title. These two questions dictate different lines of inquiry' ( $p$ 184).

(b) 'Proof of existence [of traditional title] ... is a threshold question. The content of the interests ... is that which already exists traditionally; the substance of the interests is irrelevant to the threshold question' ( $\mathrm{p}$ 187).

(c) 'the problem which arises where ... the evidence of the claimed traditional right is so vague that there is doubt that it existed, or exists ... is an evidentiary problem and the criterion for dealing with it is not the claimed right's similarity to, difference from, or even incomprehensibility at, common law. Therefore, inquiries into the nature of traditional title are essentially irrelevant' ( $p$ 187).

(d) 'an inquiry into the kind of society from which rights and duties emanate is irrelevant to the existence of title, because it is inconceivable that indigenous inhabitants in occupation of land did not have a system by which land was utilized in a way determined by that society. There must, of course, be a society sufficiently organized to create and sustain rights and duties, but there is no separate requirement to prove the kind of society beyond proof that presence on the land was part of a functioning system' ( $p$ 187).

(e) 'The requirements of proof of traditional title are a function of the protection the title provides (Bartlett 1983, 'Aboriginal Land Claims at Common Law', University of Western Australia Law Review, vol 15 293 at p 310). It is the fact of the presence of indigenous inhabitants on acquired land which precludes proprietary title in the Crown and which excites the need for protection of rights. Presence would be insufficient to establish title if it was coincidental only or truly random, having no connexion with or meaning in relation to a society's economic, cultural or religious life. It is presence amounting to occupancy which is the foundation of the title and which attracts protections, and it is that which must be proved to establish title (Bartlett 1983, vol 15 at pp 311, 319-20, See now Ontario (AttorneyGeneral) v Bear Island Foundation (1991), 83 DLR (4th) 381; Hamlet of Baker Lake [1980] FC at pp 557-8; (1979) 107 DLR (3d) at p 542; Regina $v$ Sparrow (1990) 1 SCR 1075; (1990) 70 DLR (4th) 385). Thus traditional title is rooted in physical presence. That the use of land was meaningful must be proved but it is to be understood from the point of view of the members of the society' (p 188).

(f) 'Presence on the land need not amount to possession at common law in order to amount to occupancy' (p 188). 
(g) 'proof of occupancy [may be] by reference to the demands of the land and society in question 'in accordance with the way of life, habits, customs and usages of the [indigenous people] who are its users and occupiers' ( $p$ 188).

(h) A 'principle of exclusive occupancy [of definable territory] is justified in so far as it precludes indiscriminate ranging over land but it is difficult to see the basis of the rule if it precludes title merely on the ground that more than one group utilizes land. Either each smaller group could be said to have title, comprising the right to shared use of and in accordance with traditional use; or traditional title vests in the larger 'society' comprising all the rightful occupiers. Moreover, since occupancy is a question of fact, the 'society' in occupation need not correspond to the most significant cultural group among the indigenous people' (pp 189-90).

(i) 'It is true that the findings of Moynihan J do not allow the articulation of a precise set of rules and that they are inconclusive as to how consistently a principle was applied in local law, for example, with respect to inheritance of land, but, as has been said earlier in this judgment, the particular nature of the rules which govern a society or which describe its members' relationship with land does not determine the question of traditional land rights. Because rights and duties inter se cannot be determined precisely, it does not follow that traditional rights are not to be recognized by the common law. The only relevance of an argument of uncertainty is if it can be said that the rules or practices governing Meriam society were so capricious and their application so inconsistent as to indicate that the Meriam people's presence on the Islands was coincidental and random. On the findings of Moynihan J that is impossible to conclude' (pp 191-2).

(j) 'There is no question that indigenous society can and will change on contact with European culture ... But modification of traditional society in itself does not mean traditional title no longer exists. Traditional title arises from the fact of occupation, not the occupation of a particular kind of society' ( $p$ 192).

Given the use in these judgments of this variety of terms to describe the manner in which a native title claim group may be identified, it is desirable to attempt to come to some understanding of the meanings which may be attributed to some of those terms, in order to understand how they may be used in the analysis of how one defines a group for the purposes of contemplating treaty negotiations within a nation.

\section{'Peoples' as Native Title holding communities}

The term 'peoples' is a term of International law rather than Anthropology (See expert anthropological evidence of Professor Ken Maddock in Ward (FC 1998), Ts pp 8044-5). The term 'peoples' is used in Articles 1 (2) and 55 of the Charter of the United Nations. 
In a Memorandum prepared by the United Nations Secretariat (United Nations Conference on International Organisation Docs (1945), vol 18, 657), it is said that:

The word 'nations' is broad and general enough to include colonies, mandates, protectorates and quasi-states as well as states ... 'nations' is used in the sense of all political entities, states and non-states, whereas 'peoples' refers to groups of human beings who may, or may not, comprise states or nations.

The concept of 'peoples' in International Law has evaded precise definition. It is regarded as neither co-extensive with or mutually exclusive of the categories known as 'minorities': Crawford J, 'The rights of "peoples": "peoples" or "governments"? in Crawford (ed) The Rights of Peoples (Clarendon Press, Oxford, 1988), 55 at 60-61; see also Barsh R L, 'Indigenous peoples: an emerging object of international law (1986) 80 AJILO, 369 at 376.

Nevertheless, in Cherokee Nation v State of Georgia (1831) 5 Peters 1, the Court did not have any difficulty with the concept of recognising the Plaintiffs, an indigenous group within the United States of America, who styled themselves the 'Cherokee Nation', as 'a nation within a nation'.

In Worcester v Georgia (1832), 31 US (6 Pet) 616, the United States Supreme Court said:

The Indian nations had always been considered as distinct, independent political communities, retaining their original natural rights as the undisputed possessors of the soil, from time immemorial, with the single exception of that imposed by irresistible power, which excluded them from intercourse with any other European potentate than the first discoverer of the coast of the particular region claimed.

The United States Supreme Court is in those cases recognising the indigenous title holding groups within US national borders as having the status of a political entity. A similar understanding is manifested in the order of the Court in Mabov Queensland (No 2) (supra), and the findings of Lee J in Ward (FC 1998), that a communal native title is one held by an indigenous political entity, defined by its shared customs and traditions, rather than by particular groups or individuals who hold interests within the system of law or customs of the indigenous political entity.

In the Murray Island context, the Indigenous political entity was the Meriam people and interests were held by individuals and families within a system of laws and customs recognised by the Meriam people. In the case of the Miriuwung and Gajerrong people(s) intra-community interests may be described as estate areas or local descent group areas in respect of a larger community of people who share customs and traditions.

In the circumstances of the Miriuwung and Gajerrong peoples' case, the Court recognised the Indigenous groups as comprising 'peoples' who do not comprise states or nations recognised as such in the International community. Likewise, the term 'people', as used in Mabo (No 2) (supra) is clearly something less than a nation or state recognised by other nations at an International level. 
A 'people' is clearly larger than an individual or a family, which may hold an interest in particular land on Murray Island. It was also held, in the Ward (FC 1998) case (at p 542), to be larger than an estate group or local group holding an interest in a locally defined tract of land.

In Mabo (No 2) (supra) the Court was using 'people' to refer to a group of Melanesian origin or of Torres Strait Islander origin. The 'people' thus referred to were a group greater than those (defined by the pleadings as 'the Meriam people'), who held a communal native title to the Murray Islands.

'People', as used by Brennan and Toohey JJ in Mabo (No 2), is a broader term than 'society', as used by Toohey J in Mabo (No 2) (supra) and 'community', as used by Brennan J.

The appropriate analysis, I would suggest, for international and domestic law purposes, is to find a 'people' from those Indigenous groups who share customs and traditions amongst themselves. That is the most appropriate group to be seeking to identify in Australia for the purpose of entering into treaties of the kind which in North America have been entered into with 'indigenous political communities' (who describe themselves as 'nations').

\section{Communities as Native Title Holders}

What is comprised by a community, for the purposes of identifying those who are associated with a communal native title may be difficult. It is a commonly held view that a 'community definition is bound to be arbitrary and imposed' (see the expert aaaanthropological evidence of Associate Professor Christensen in Ward (FC 1998), Ts p 7247). Different communities are developed depending on the context.

A communal native title may be held by a community located in a particular area who form part of a 'people' or 'society' (such as the 'Meriam people' who were a community located in the Murray Islands).

Within that community particular individuals, local groups or estate groups may hold particular interests in accordance with the laws and customs recognised by the larger 'community', 'society' or 'people'.

\section{'Tribe' or language group}

The concepts of 'tribe' and 'language group', also overlap in meaning and content with the concepts of 'community', 'society' and 'people'. They, therefore, merit some discussion.

Australian anthropologists, Peter Sutton and Bruce Rigsby have referred to the 'new tribes' or language groups. Sutton suggests that:

one of the consequences of the impact of the colonial period in Aboriginal Australia has been the rapid rise in the political importance of the language group. In some areas, this has become the main collective label under which people maintain a local Aboriginal identity and a communal land-owning group identity: Sutton, Country: Aboriginal boundaries and land ownership in Australia: Aboriginal History Inc, Monograph 3, 1995, p 47; Sutton, Native Title and the Descent of Rights: National Native Title Tribunal 1998. 
Sutton points out, however, in Native Title and the Descent of Rights, at p 55, that language groups or 'regional groups' have an internal structure, typically comprising a set of units usually referred to as 'families'. He notes (at p 56) that a human family is 'always a jural construct and never merely a biological or demographic datum. This is because it belongs to the realm of kinship, or recognised genealogical relationships, rather than merely to the reproductive history of some randomly selected set of individuals.'

Sutton puts the view (at $\mathrm{p}$ 60) that the cognatic descent group is central to a post-colonial Aboriginal social system. He explains that a cognatic descent group is 'one formed by those who share recognised descent from a particular ancestor or set of blood-related ancestors, and who trace their links to such ancestors through either parent'. He describes them as 'families of polity in the sense that they form structural elements of public life in Aboriginal society'.

Sutton goes on (at p 63) to refer to 'Tribal units [which] are usually much larger than cognatic descent groups and are based on language affiliation, or occasionally another type of regional affiliation such as a nation (descendents of members of several language groups combined)'.

Sutton's analysis is consistent with the conclusions reached by the High Court in Mabo and the Federal Court in $\operatorname{Ward}$ (FC, 1998 and FFC, 2000) as to the nature of the groups comprising the Meriam people and the Miriuwung and Gajerrong peoples. Sutton would describe those native title holding groups as 'tribal units' and is adopting a use of the word 'nation' which is distinguishable from its use in International law or its application by the US Supreme Court to Native American groups. Sutton is also assigning language groups to the status of a category of tribal unit.

'Tribe' is a classification sourced in anthropological study, generally regarded as describing Indigenous peoples who share a common purpose, language and culture. It is a category which is not popular with Indigenous peoples or in modern anthropological discourse, because it does not have a consistent meaning and has a tendency to promote misleading stereotypes.

Chris Lowe of the Africa Policy Information Center in 'Talking about "Tribe", Background Paper, at www.africaaction.org/bp/ethall.htm, wrote:

If by tribe we mean a social group that shares a single territory, a single language, a single political unit, a shared religious tradition, a similar economic system, and common cultural practices, such a group is rarely found in the real world. These characteristics almost always never correspond precisely with each other today, nor did they at any time in the past.

Lowe argues that the use of the word 'tribe' tends to promote a destructive generalised illusion, myth or stereotype of primitiveness, conservative backwardness and images of irrationality and superstition which avoids any detailed analysis of ethnic groups. This idea that a 'tribal' group was a primitive group or of a lower order of humanity justified Europeans in adopting a position of domination. It also justified the taking of the land and resources of so called 'tribal' groups in return for providing them with European civilisation.

It is for those reasons that there is a general aversion to the use of that term today, in favour of terms with less negative connotations. 
In the United States there is a continued use of the term because it is an historical term ensconced in treaties and laws which accord rights to Native Americans. Also, Indigenous people will sometimes refer to themselves by that term because they are of the view that it is one which will be recognised by English speaking Europeans, but it is regarded as offensive by many Australian Aboriginal groups: see Glossary for Aboriginal Studies, Charles Sturt University, hsc.csu.edu.au/ab_studies/glossary2.htm

\section{Negotiating a treaty}

In the current debate concerning the concept of 'treaty' much energy has been focused upon negotiation by the Australian Nation with the Indigenous or the Aboriginal and Torres Strait Islander peoples of Australia.

In my view the most appropriate group for Indigenous and non-Indigenous stakeholders to commence negotiation of a treaty is with each Indigenous or Aboriginal or Torres Strait Islander group, whether styling itself a 'community', 'people', 'society' or 'nation', which adheres to a common set of laws and customs which control its behaviour. That group will ordinarily be co-extensive with the group who, at least at the time of colonisation, held the communal native title for an area. That form of group will ordinarily be found to be in the nature of a polity which governs itself in accordance with its laws and customs.

If a treaty can be agreed with such a group then it provides a building block upon which treaties within the Australian nation can be recognised at regional, State, national and international levels.

The advantage for Aboriginal and Torres Strait Islander leaders, throughout the nation, of commencing at that level is that it focuses them where they know they need to be focused, within the groups who provide them with their traditional base of law and custom. Aboriginal and Torres Strait Islander people who operate in a regional, national and international context for the benefit of their people recognise that their legitimacy as representatives of their people at those levels must always be grounded in the traditions of the families and local communities from which they come.

The advantage for the broader Australian community of commencing negotiation of a treaty at a local communal level is that it has the potential to engage local urban and rural communities in identifying and understanding the aspirations of local Indigenous and nonIndigenous groups through communication at a personal level. Experience suggests that when individuals communicate at a personal level there is more chance of them understanding and sympathising with one another's aspirations. It provides an opportunity to strip away misunderstanding, pre-judgments and fears about positions being taken which will advantage one group to the disadvantage of a competing group. Ultimately, when individuals confront each other, as individuals, there is a reasonable chance that they will come to understand that their aspirations for a just outcome for themselves and their families are similar. It is from that base that an accommodation may be able to be negotiated. That is the most likely base from which a true reconciliation between Indigenous and non-Indigenous peoples may emerge in Australia. 
If Indigenous and non-Indigenous people understand each other and come to agreements about how they can live together in an atmosphere of mutual respect at a local level, in the many urban and rural regions of the nation, then they will be more confident about expressing their accommodation of one another in the form of uniform or similarly drafted documents which apply across regions, States and the nation.

That confidence, based upon a nationally pervasive mutual understanding, may in the fullness of time eventually mature into a degree of acceptance of the existence and rights of Aboriginal and Torres Strait Islander Peoples in Australia which:

(a) will carry with it a groundswell of public opinion sufficient to assure an amendment to the Australian Constitution which recognises the rights of Indigenous peoples as polities operating within Australian society; and

(b) allows our nation to feel free to proclaim its recognition at an international level of the agreements it is able to reach with the self determining polities of Aboriginal and Torres Strait Islander peoples in the Australian Nation.

\section{Conclusion}

The Aboriginal and Torres Strait Islander Commission, National Treaty Support Group, in its publications under the title: 'Treaty: let's get it right! Frequently Asked Questions', suggests that the discussion it is promoting about a treaty will allow Aboriginal and Torres Strait Islander peoples to look at the different forms a treaty might take. It suggests that there might be:

$$
\begin{aligned}
& \text { - one national treaty; } \\
& \text { - a national agreement of principles that allows for } \\
& \text { treaties to be signed at the regional level; or } \\
& \text { - a network of regional or local treaties. }
\end{aligned}
$$

The approach this paper recommends is that, provided the negotiations commence at the local level, it may be possible that all of the above alternatives can be achieved, and that, indeed, that may be the most appropriate result.

It is more likely if agreement is reached at a local level in relation to locally significant issues that the necessary goodwill will be engendered to reach agreement at regional levels. It may then be possible to identify from local and regional agreements universal principles which can be nationally agreed, resulting in the possibility of a national treaty of international significance. 


\section{References}

\section{Books, articles and reports}

Aboriginal and Torres Strait Islander Commission, National Treaty Support Group, 'Treaty: let's get it right! Frequently Asked Questions', ATSIC, Canberra.

Barsh, RL 1986, 'Indigenous peoples: an emerging object of international law', 80 AJILO.

Bartlett, RH 1983, 'Aboriginal Land Claims at Common Law', 15 University of Western Australia Law Review.

Crawford, J 1988, “The rights of "peoples": "peoples" or "governments"?' in J Crawford (ed) The Rights of Peoples, Clarendon Press, Oxford.

Glossary for Aboriginal Studies, Charles Sturt University, available at hsc.csu.edu.au/ab_ studies/glossary2.htm

Lowe, Chris, (Africa Policy Information Center) 1997, 'Talking about “Tribe”, Background Paper, available at www.africaaction.org/bp/ethall.htm, viewed 1 December 2006.

McNeil, Kent 2001, The Relevance of Traditional Laws and Customs to the Existence and Content of Native Title at Common Law, available at www. usask.ca/native law, viewed 19 September 2001.

Meyers, Gary 2000, 'The Content of Native Title: Questions for the Miriuwung Gajerrong Appeal' in Land, Rights, Laws: Issues of Native Title, Native Title Research Unit, Australian Institute of Aboriginal and Torres Strait Islander Studies, vol 2, November, Issues paper no 7.

Pearson, Noel 1996, Concept of Native Title at Common Law, paper presented at Conference on Land Rights - Past, Present and Future, Canberra, 16-17 August.

Sutton, P 1995, Country: Aboriginal boundaries and land ownership in Australia, Aboriginal History Inc Monograph 3, Canberra.

— 1998, Native Title and the Descent of Rights, National Native Title Tribunal, Perth.

\section{International charter and memorandum}

Charter of the United Nations 1945, UN, San Francisco.

Memorandum prepared by the United Nations

Secretariat, United Nations Conference on International Organisation Docs (1945), vol 18.

\section{Case law}

Cherokee Nation v State of Georgia (1831) 5 Peters 1.

Delgamuukw v The Queen in Right of British Columbia (Supreme Court of Canada, 11 December 1997) (1998) 1 CNLR 14

Hamlet of Baker Lake [1980] FC at pp 557-8; (1979) 107 DLR (3d) at p 542.

Mabo and Ors $v$ The State of Queensland (No 2) (1992) 175 CLR 1.

Ontario (Attorney-General) v Bear Island Foundation (1991), 83 DLR (4th) 381.

Regina v Sparrow (1990) 1 SCR 1075; (1990) 70 DLR (4th) 385 .

Ward on behalf of the Miriuwung and Gajerrong Peoples v State of Western Australia (1998) 159 ALR 483.

United States v Santa Fe Railroad Co (1941) 314 US, 339.

Western Australia v Ward (2000) 170 ALR 159.

Worcester v Georgia (1832), 31 US (6 Pet) 616. 